\title{
REPORT OF A CASE OF A PRIMARY CARCINOMA OF LACRIMAL SAC*
}

BY

W. L. ROBERTS, M.D.

U.S.A.

and

J. R. WhEELER, F.R.C.S.

OPHTHALMIC HOSPITAL, BELFAST

BECAUSE of the infrequent occurrence of a primary tumour of the lacrimal sac we feel justified in presenting the following case. Penman and Wolff ${ }^{1}$ collected data on 64 cases reported up to 1938. They observed the following distribution pathologically :

$\begin{array}{lllllr}\text { Adenoma } & \ldots & \ldots & \ldots & \ldots & 1 \\ \text { Carcinoma } & \ldots & \ldots & \ldots & \ldots & 24 \\ \text { Endothelioma } & \ldots & \ldots & \ldots & \ldots & 4 \\ \text { Fibroma } & \ldots & \ldots & \ldots & \ldots & 2 \\ \text { Lymphoma } & \ldots & \ldots & \ldots & \ldots & 5 \\ \text { Papilloma } & \ldots & \ldots & \ldots & \ldots & 7 \\ \text { Plasmocytoma } & \ldots & \ldots & \ldots & \ldots & 1 \\ \text { Sarcoma } & \ldots & \ldots & \ldots & \ldots & 20\end{array}$

Spratt ${ }^{2}$ gives the most recent summary of previously reported cases. The consensus of opinion of the best method of treatment is that of surgical removal of the tumour mass, followed by exposure to X-ray or radium. The prognosis is ussually good, especially if there is no extension outside the lacrimal sac.

The patient is a 49 years old white male. He first noticed watering in the right eye in November, 1942. This condition persisted and one month later a tender swelling was noticed over the right tear sac. This swelling later became quite painful. There were no symptoms referable to the nose and throat. The watering persisted but at no time did the patient complain of purulent discharge in the right eye.

Patient was sent to the Ophthalmic Clinic by his panel doctor on March 22, 1943. Examination at this time was as follows:

Vision Rt. -0.50 D.Sph., +0.75 D.Cyl. $\times 85^{\circ}=6 / 9$. Vision Lt. -0.75 D.Sph., -0.50 D. Cyl. $\times 180^{\circ}=6 / 9$. Slight injection of palpebral conjunctiva right eye. Media and fundus normal both eyes. In the region of the right tear sac there was a mass about the size and shape of a bean. Mass was firm and slightly tender.

An attempt to irrigate the right lacrimal sac was unsuccessful and an examination of the nose at this time failed to reveal any pathology. In April, 1943, patient noticed a bloody discharge from the right nasal passage and a nasal obstruction in this area. 
Patient was admitted to hospital on July 13,1943 , for observation. The examination at this time revealed a great increase in the size of the swelling of the right lacrimal sac. This mass was very tender to palpation. An examination of the nose revealed a granular mass in the region of the right middle turbinate which was almost completely obstructing the right nasal passage. There was slight bleeding from this mass. A biopsy was taken of the intra-nasal growth and the following report was obtained :

"The material consists mainly of blood clot and fragments of oedematous fibrous tissue. At one point the clot shows early organization by fibroblasts. It is impossible from the material supplied to report on the malignancy. No tumour tissue was present."

On August 2, 19.43, a dacryocystectomy was done with complete removal of the tumour mass. The mass had invaded the lacrimal bone but there was no evidence of any extension into the frontal sinus. At the time of operation the middle turbinate of the right nose was also removed. Both specimens from tear sac and nose were sent for pathological examination: The pathological report of the lacrimal sac follows :

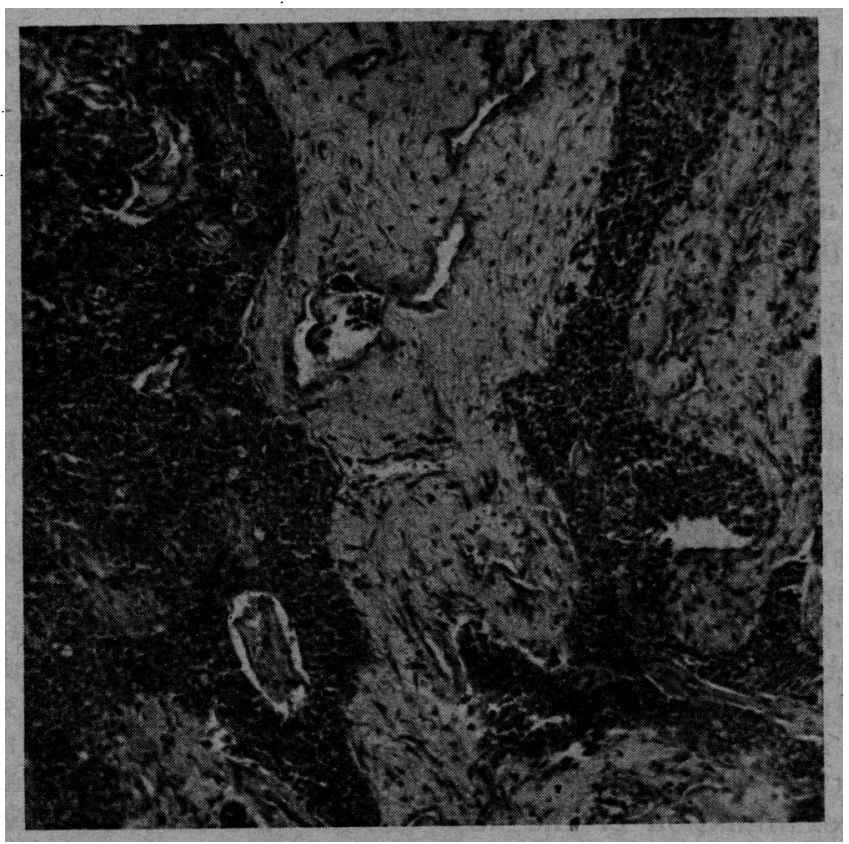

FIG. 1 .

To show invasion of the submucosal tissue by columns of epithelium. Each column is limited by a'layer of basal epithelium. 


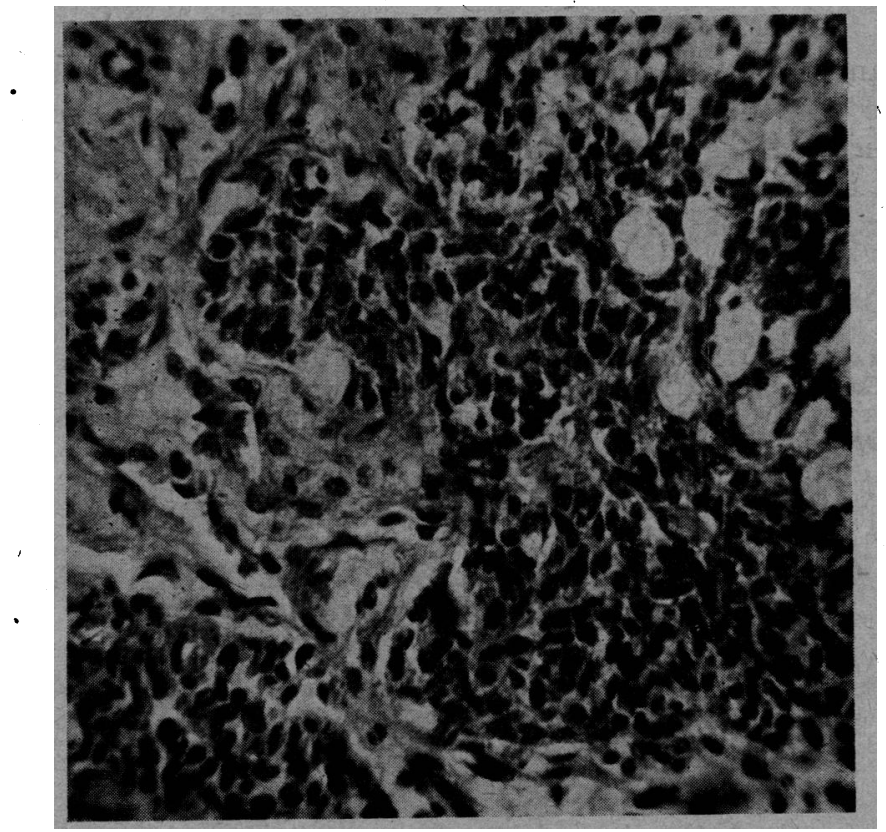

Fig. 2.

To show the rather oval epithelial cells which are found generally throughout the tumour.

"The tissue is largely composed of small oval, or rather spindle shaped cells with very scanty cytoplasm and dense hyperchromatic nuclei. These tend to grow in sheets of broad strands with very little stroma and to infiltrate widely through the oedematous subepithelial connective tissue. Very occasionally they are arranged around a small acinar-like space, and this very abortive attempt to form acini is evidence of their epithelial origin. The tumour has arisen from basal cells of the epithelium and histologically has some resemblance to an oat cell carcinoma of the lung. There is no calcification of blood vessel walls."

Turbinate from nose :

"The sub-epithelial connective tissue is invaded in some areas by tumour cells similar to those of the lacrimal sac. The tumour is likely to prove relatively malignant, but to spread by direct extension, rather than by distant metastases, and to react moderately well to irradiation."

On August 13, 1943,6.9 mgs. of radium was inserted for 12 hours into the region where the sac had been removed, and $9.4 \mathrm{mgs}$. to region where middle turbinate had been removed. The subsequent post operative course was uneventful and the lacrimal sac wound and nose healed without any recurrence of the mass to date. When last examined, on October 20,1943, patient was in good 
health. Nose revealed no obstructive mass and the mucous membrane appeared normal. The incisional scar over the right tear sac was healthy in appearance and there was no evident recurrence of the growth. Patient no longer complained of watering.

Until the patient has been followed for a much longer period of time the results of the treatment administered cannot be determined.

\title{
REFERENCES
}

1. Penman, G. G. and Wolff; E-Primary tumours of the lacrimal sac. Lancet, Vol. II, pp. 1325, 1938 . Reviews the literature.

2. SPRATT, G. N.-Carcinoma of the lacrimal sac; report of a second case. Arch. Ophthal., Vol. XXIV, pp. 1237-1243, 1940.

\section{A CASE OF RUPTURE OF A RETINAL CYST CAUSING RETINAL DETACHMENT}

BY

\author{
Major C. DEe Shapland \\ R.A.M.C.
}

- CASES of retinal detachment clearly due to the spontaneous rupture of a retinal cyst are not common and hence this case is deemed worthy of placing on record, especially so as it clearly showed that a retinal dialysis or disinsertion can be produced by such a rupture.

J. S., aged 28 years, a private of the 8 th Black Watch, was sent to the Ophthalmic Department of the Royal Victoria Hospital, Netley. on September 18, 1943, on account of failirg vision in the right eye noticed during the previous six weeks. The acuity of his right eye had been recorded as $6 / \dot{6}$ unaided on his examination by a civilián medical board on April 20,1940, and he was placed in Grade 1, being subsequently re-examined on May 16, 1940, and placed in Army Category $\mathrm{Al}$. He was re-examined medically on June 4 and November 13.19+2, and no change made in his category. On August 2, 194.3, the day before J. S. had first noticed the right vision to be misty, he had felt a sudden. sharp, shooting pain lasting some two to three minutes in the region of the right temple " just where the veins are". and felt giddy and faint. He was marching out of canp at the time in full equipment and wearing a steel helmet. He did not, however, report this occurrence and the subsequent blurring of his right vision to his unit M.O. untíl September 17, 1943.

On examination on September 20,194.3, the right eye was white, there were no keratic precipitates, the pupil was active and tension normal; a few coarse vitreous opacities were present below. Extending from 6.30 to 11 o'clock temporally was a flat detachment of the retina of recent origin with the macula involved, central 